\title{
SOUTHERLY MOVEMENTS OF WILLOW PTARMIGAN DURING WINTER IN AND NEAR THE PRAIRIE PROVINCES
}

Peter Taylor

P.O. Box 597

Pinawa, MB R0E 1L0

taylorp@granite.mb.ca

This review was inspired by a cluster of three records of Willow Ptarmigan (Lagopus lagopus; hereafter, WIPT) in southeastern Manitoba in December 2017. On 11 December, Richard Farquhar photographed two WIPT alongside Manitoba Provincial Road 315 in a forested area near Poplar Bay at the eastern end of Lac du Bonnet [lake] $\left(50.37^{\circ} \mathrm{N}, 95.77^{\circ} \mathrm{W}\right)$. On 27 December, while scouting for the annual Pinawa - Lac du Bonnet Christmas Bird Count (CBC), Anita Drabyk and I saw and photographed a WIPT at a small patch of deciduous trees and willows in open farmland along Belluk Road $\left(50.24^{\circ} \mathrm{N}\right.$, $95.91^{\circ} \mathrm{W}, 11 \mathrm{~km}$ east of Lac du Bonnet [town] and $18 \mathrm{~km}$ southwest of the Poplar Bay sighting). Though only a "count week" observation, this furnished the first $C B C$ record of a ptarmigan for southern Manitoba. ${ }^{1}$ On 29 December, Daniel Seales photographed a WIPT at Barrier Bay $\left(50.18^{\circ} \mathrm{N}, 95.71^{\circ} \mathrm{W} ; 16 \mathrm{~km}\right.$ southeast of the Belluk Road sighting) in

Whiteshell Provincial Park. It was also seen and photographed by Charissa Godfrey on or about the same date.

Figure 1 is a photo montage documenting these three records, which probably involved four different birds; others likely visited the region, passing unseen or at least unreported. The three localities described above are included in the map, Figure 2, which shows many of the additional localities mentioned in the following sections.

To prepare this article, I consulted many books, reports and journal articles, newspaper articles (especially the erstwhile Chickadee Notes column in the Winnipeg Free Press, successively edited by Alexander Lawrence, Harold Mossop, and David Hatch), individual correspondents cited in the acknowledgements, and open-access online resources (especially VertNet, eBird, GBIF, iNaturalist, the Searchable Ornithological Research Archive (SORA), and several individual online museum databases). This resulted in more records, anecdotes, and references than I could include in this article.

\section{Observations Elsewhere in Winter 2017-2018}

There were no further WIPT records in SE Manitoba in winter 2017-18 despite numerous searches, inquiries in the local press, online bird discussions, and correspondence with Manitoba Conservation staff. Elsewhere, reports and correspondence pointed to unusual southerly movements in central Manitoba, NW Ontario, and NE Alberta, but apparently not in Saskatchewan, eastern Ontario, or Québec.

Central Manitoba - Writing on 5 February 2018, Joel Kayer reported unusually high numbers of WIPT near The Pas and southward to about $53^{\circ} \mathrm{N}$ in central western Manitoba, starting in November 2017. He wrote to me: "There was an early spurt of ptarmigan locally in early November of singles and small groups and then in late November and early December a big push of flocks moving through. Locally they are scarce right now except for pockets in which they are wintering. About a month ago [early January] there were numerous sightings of flocks on Highway 60 and in the bog area [northwest of Lake Winnipegosis]. I expect they are wintering on Lake Winnipegosis or in the bog area. Some years they shift east from this area, and I expect the same has happened [this year] as in early December there were numerous sightings on Highway 6 between William Lake and Ponton. Historically they are said to have wintered quite far south on Lake Winnipegosis. This year's sightings are the most southerly I have heard of by far. Normally the main push of them is in February when they will winter in a small area to the north of The Pas."

Writing on 5 February 2018, David Raitt confirmed Kayer's assessment and added: "I know of three [ptarmigan] hit by a car on Highway 10 near Lake Winnipegosis around Christmas [2017]." On 31 March 2018, two WIPT were photographed at Grand Rapids by Lee Adam (eBird).

No ptarmigan was recorded on any of $11 \mathrm{CBCs}$ at The Pas between 2009 and 2019, which is consistent with Kayer's description of sometimes widespread migrants but more localized wintering. Writing later (8 June 2020), Kayer and Raitt clarified that, when present in numbers near The Pas, WIPT may be encountered in groups of 10-20 birds, which sometime combine into flocks of up to 40 . In some winters, such as 2019-20, ptarmigan are scarce in the region, with records limited to a few individuals. 
Northwestern Ontario - Devin Turner, a wildlife biologist based in northwestern Ontario, was informed of a group of ptarmigan (a photograph by an unidentified observer shows three) at Pahngwahshahshk Ohweemushkeeg Provincial Park, between Red Lake and North Spirit Lake in January 2018. Further correspondence received by Turner in March 2018 mentioned unusually large numbers of wintering ptarmigan farther northeast, in and around North Spirit Lake, and he forwarded several identifiable photographs taken by a local resident. Josh Vandermeulen, who compiles Ontario winter reports for North American Birds (NAB), was not aware of any unusual ptarmigan movements in more easterly parts of northern Ontario in 2017-18 or other recent winters, but he remarked that there is virtually no coverage of remote winter roads by birders.
Northern Alberta - Writing on 23 July 2018, Alberta birder James Fox told me: "There was a major invasion of Willow Ptarmigan this past winter. Every few years a few ptarmigan end up in Fort McMurray; this is as far south as they [normally] go. But this year there were huge numbers and they stayed much longer than usual, well into March. Oil companies were seeking advice from a consulting biologist on keeping the ptarmigan off the roads to avoid running

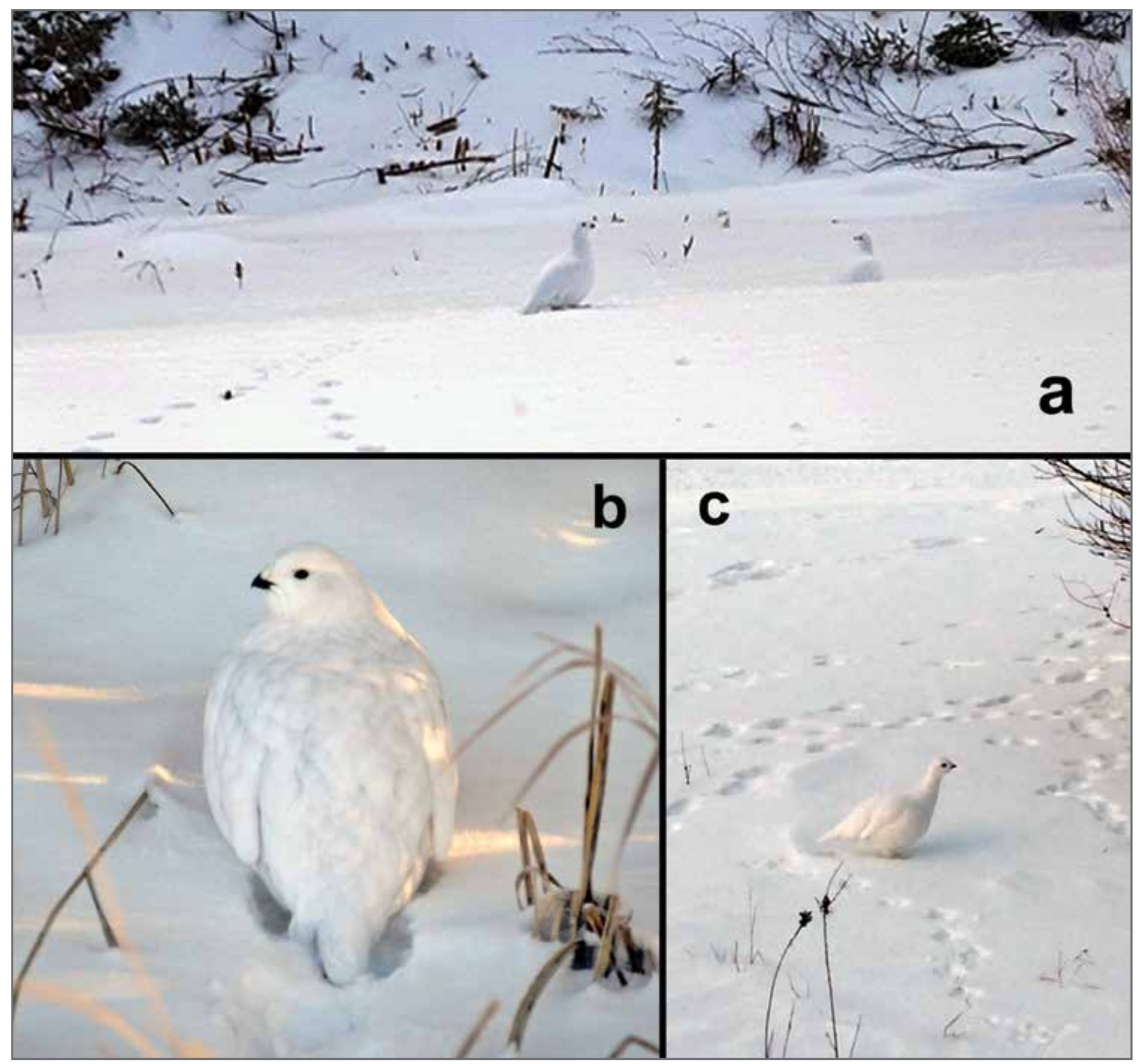

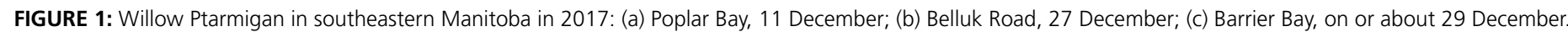
Photo credits: Richard Farquhar, Peter Taylor, Charissa Godfrey. 
them over. The last eBird record on 18 March is one of the latest ever. Normally they're back in the Northwest Territories by the end of February."

Consistent with this summary, WIPT were recorded on 13 of 33 CBCs at Fort McMurray since 1981 (including three count-week records), with a maximum of 34 on 20 December 1998. Only one was recorded on 16 December 2017, suggesting that the CBC preceded the main winter influx. The eBird database shows a cluster of records of up to 40 WIPT in the Fort McMurray area between 23 December 2017 and 18 March 2018.

Central Saskatchewan - Creighton, Saskatchewan and nearby Flin Flon, Manitoba are near the normal southern limit of the WIPT's winter range. ${ }^{2,3}$ An average of 27 WIPT were recorded on 12 consecutive Creighton CBCs between 2006 and 2017. The maximum of 76 on 2 January 2009 furnishing the highestever provincial count total, the minimum was one on 30 December 2016, while 16 were tallied on 16 December 2017. ${ }^{1}$ The eBird database includes numerous records of WIPT in the Creighton - Flin Flon area between 1 December 2017 and 10 April 2018. Regarding the 2017-18 winter, however, Creighton resident Harvey Schmidt (whose wife Brenda wrote the WIPT account for Birds of Saskatchewan ${ }^{3}$ ) informed me: "This year seems normal or slightly above normal, but definitely not a high in this area. We are noticing tracks along the highway further south, so there seems to be some southward movement." Elsewhere in Saskatchewan, the most southerly winter 2017-18 records (based on eBird) were in the Narrow Hills Deschambault Lake area, about $100 \mathrm{~km}$ west and slightly south of Creighton (Figure 3).

Québec - Reports on eBird show that WIPT moved well southeast of James Bay in winter 2017-18, with records of up to 14 as far south as Rapide-des-Cèdres in early February. However, Normand David and Pierre Bannon, two of the Québec provincial editors for $N A B$, did not consider this movement to be exceptional (email to PT). Records along the north shore of the Gulf of St. Lawrence, between Rivière-aux-Graines and Mingan, were also close to the normal limits of winter movement. Pierre noted a much greater movement the previous winter, including an estimate of 1,500 WIPT at the LG-3 hydroelectric dam on the La Grande River about $150 \mathrm{~km}$ east of James Bay on 21 November 2016.

Elsewhere - Inquiries to several other $N A B$ regional editors did not reveal any ptarmigan reaching the conterminous U.S.A. (where records are extremely rare) in winter 2017-18.

\section{Geographical and historical context}

This section is primarily concerned with the three Prairie Provinces. Information for other parts of Canada and the northern United States is provided for context, but is not comprehensive.

\section{Canada-wide - The Willow} Ptarmigan breeds extensively in low-Arctic and some alpine and moorland regions of North America and Eurasia. ${ }^{4,5}$ The North American breeding range extends from Alaska to Newfoundland, skirting Hudson Bay and northern parts of James Bay, extending southward in the western mountains to southern British Columbia, and reaching the north shore of the Gulf of St. Lawrence in extreme eastern Québec. ${ }^{4,5}$ Breeding in the Prairie Provinces is limited to extreme northern Manitoba (mostly within $100 \mathrm{~km}$ of the Hudson Bay

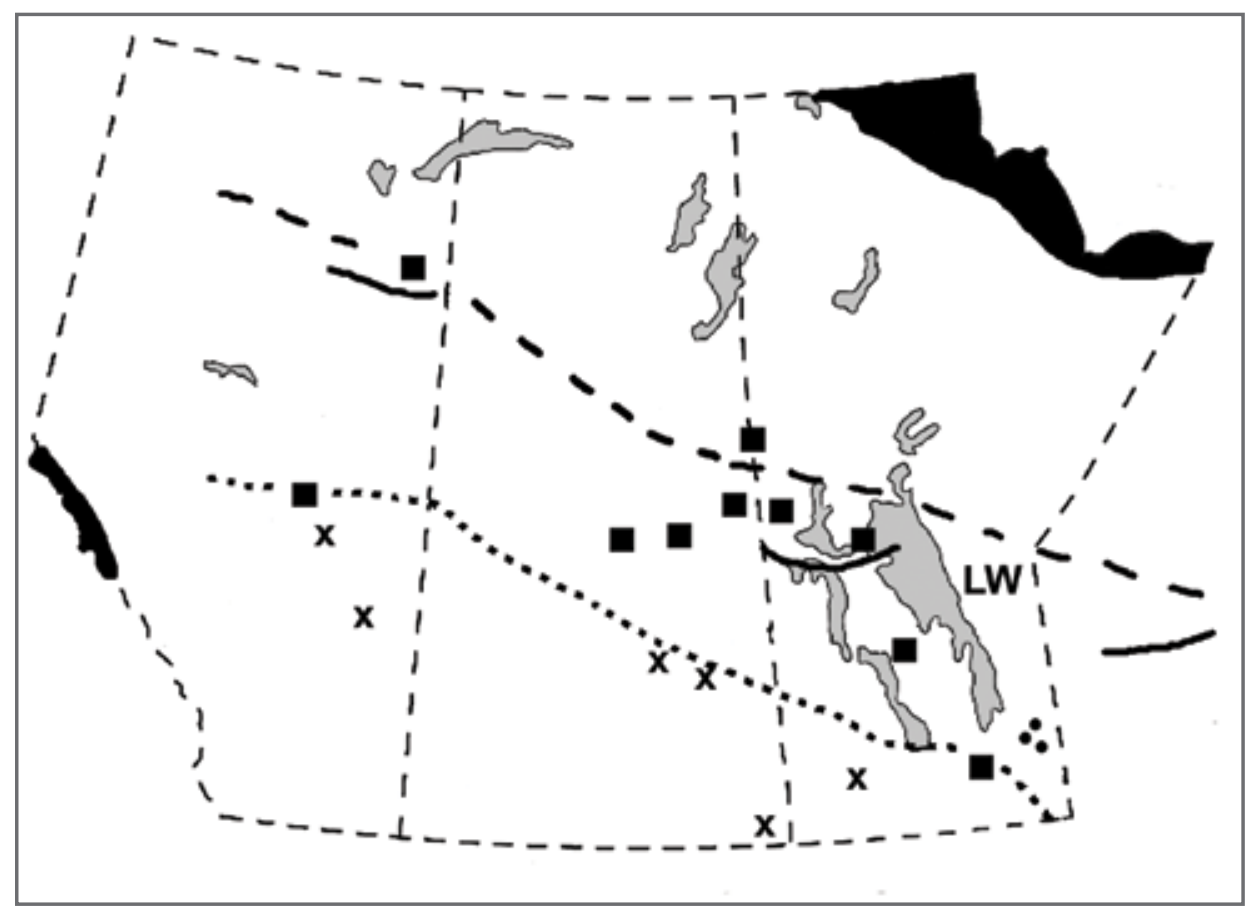

FIGURE 2: Summary of occurrences of Willow Ptarmigan in the three Prairie Provinces. Solid black areas represent the breeding range. Bold, dashed line is estimated extent of normal southward movements. Dotted line is estimated, combined extent of irruptions in the early 1930s (see text). Three dots show the December 2017 locations in SE Manitoba. Three short, solid lines show the known extent of large movements in 2017-18 winter in Alberta, Manitoba, and NW Ontario. indicates important localities mentioned in the text, from west to east: Edmonton and Fort McMurray, Alberta; Prince Albert, Nipawin, and Cumberland House, Saskatchewan; Creighton, Saskatchewan / Flin Flon, Manitoba; The Pas, Grand Rapids, Gypsumville, and Winnipeg, Manitoba. $\mathbf{X}$ indicates outlying southerly records, from west to east: Camrose and Sullivan Lake, Alberta; Dafoe, Sheho, and Carnduff, Saskatchewan; Aweme, Manitoba. LW = Lake Winnipeg. The three water bodies immediately west of Lake Winnipeg, from south to north, are Lake Manitoba, Lake Winnipegosis, and the Cedar-Moose lakes complex. Note that there are five records for North Dakota. The only Montana record was just south of the British Columbia border, and presumably associated with the montane population. ${ }^{58}$ No attempt is made to show the winter range in mountainous parts of Alberta. 
coast, but farther inland along the Nunavut border) and a small portion of western Alberta in and near Jasper National Park. 2,6,7

Though some WIPT remain throughout much of the breeding range in winter, others move into the northern boreal forest each year, with sporadic movements much farther south. ${ }^{2,3,8-10}$ Female WIPT tend to migrate longer distances than males. ${ }^{10,11}$ Because ptarmigan migration crosses sparsely populated regions of the boreal forest, often concentrating in inaccessible areas, this migration is a rather ghostly phenomenon (appropriate for white winter plumage!) with fragmentary records. ${ }^{10}$ Based on inquiries to conservation officers and other boreal-forest residents in the early 1970s, Höhn found that migrating WIPT tended to show "two separate periods of prevalence" in early and late winter in the northern boreal forest, indicative of southbound and northbound movements, but occurred mainly in the mid-winter period (November to February) farther south. ${ }^{10}$ This pattern held true in the 1974-75 winter, when ptarmigan numbers were below average. ${ }^{10}$ Only rarely do any ptarmigan appear at or beyond the southern fringe of the forest, sometimes upwards of $1,000 \mathrm{~km}$ from their breeding range. There is evidence of a reduction in the magnitude and extent of southern movements over the past two centuries. $^{3,12,13}$

This complex situation probably accounts for the different depictions of WIPT winter range in various field guides and other publications. Peterson illustrated the situation succinctly by drawing a dashed boundary through the mid-boreal forest, but annotating the map with a note on casual or accidental occurrence much farther south. ${ }^{14}$ Similarly, the map of estimated winter range in The Birds of Manitoba is divided into "sporadic" occurrence south to a diagonal line passing the north end of Lake Winnipeg and "extremely rare" south to a line that excludes only the most intensively farmed (former prairie) regions of southwestern and central southern Manitoba. ${ }^{2}$ This is slightly farther south than the estimated winter range boundary in Birds of North America, but supported by 20th century records discussed here. ${ }^{5}$

In The Birds of Canada, Godfrey defined the southern limit of irregular WIPT migration by mentioning the following localities: Camrose and Sullivan Lake, Alberta; Qu'Appelle Valley, Saskatchewan (rarely); Gypsumville, Ashern, and southern Lake Manitoba, Manitoba; central Ontario (rarely south to Whitby); Chelsea and perhaps Montréal, Québec. ${ }^{4}$ Note that the occurrence in the Qu'Appelle Valley, originally mentioned by Mitchell, is not substantiated, but there is at least one valid record farther south. ${ }^{3}$

The winter diet of WIPT is mostly willow (Salix spp.) and birch (Betula spp.) buds and twiglets (Figure 4), so that occurrence in any region of the boreal forest is localized. ${ }^{10}$ Prime habitat for hunting ptarmigan in winter has been described as "clusters of small lakes with expansive willow and alder bushes growing along the shorelines, as well as low-lying marshy river segments that back onto old-growth conifer stands... [with] patchy burns or exposed rocky ledges for grit." 15

Québec - The strongest statements about diminished migration of WIPT since the 19th century come from Québec.. ${ }^{12}$ While winter movements may exceed 1,000 $\mathrm{km}$, and occasional incursions still reach the Abitibi, Saguenay - Lac St. Jean, and North Shore (St. Lawrence) regions (collectively, 48.5 to $49.0^{\circ} \mathrm{N}$,
69 to $\left.78^{\circ} \mathrm{W}\right)$, Lamothe and Doyon stated that such movements involve fewer and fewer birds. ${ }^{12}$ They cited reports of tens of thousands taken by hunters in 1885, 1895, and 1904; the decade-long intervals apparently reflect cyclic population changes. ${ }^{12,16}$

Ontario - Based on accounts of early settlers in southern Ontario, ptarmigan were apparently "frequent migrants into the townships back of Darlington [43.9 $\left.{ }^{\circ} \mathrm{N}, 78.7^{\circ} \mathrm{W}\right]^{\prime \prime}$, east of Toronto in the 19th century. ${ }^{17}$ Again, the extent of regular migration seems to have diminished during the 19th century, such that recent, unseasonal occurrences at Toronto and Darlington were extreme rarities. ${ }^{18}$ An "unusually southern" migration in winter 1896-97 brought WIPT as far south as Lake Nipissing and the Parry Sound district east of Lake Huron. ${ }^{17,19}$ Records for northwestern Ontario are sparse, but Speirs cited regular winter occurrence at Big Trout Lake and Nikip Lake. ${ }^{20}$

Manitoba - The three records in December 2017 that inspired this article were clustered about $60 \mathrm{~km}$ SE of Lake Winnipeg. A number of historical records of wintering WIPT on or near this lake, which extends about $400 \mathrm{~km}$ from north to south, provide local context. The summary by Donald Gunn, as quoted by Ernest Thompson [Seton], is helpful: "Very seldom to be seen south or west of Lake Winnipeg, but is found in all of the country north and east of that lake during the winter season." 21 Writing of Swamp [or Swampy] Island, now known as Berens Island, a Mr. Plunkett (also cited by Seton) stated that WIPT were common in severe winters only. He noted 20 on 16 February 1885, and described the species as abundant the following winter, with records between 12 January and 8 March 1886. ${ }^{21}$

An explorer from lowa, Frank Russell obtained 15 WIPT specimens between 12 November 1892 
and 8 February 1893, when he overwintered at Grand Rapids; 10 of these are still held at the University of lowa Museum of Natural History. ${ }^{22,23}$ He stated that they frequented the sandy dikes of the lake shore, feeding on willow buds, noting that "the ptarmigan were not abundant this season", and that he never secured more than two or three usable specimens in a day's hunt. More recent records at Grand Rapids of four WIPT on 16 February 1979 (Dominic French) and two photographed on 31 March 2018 (see p. 13) seem more noteworthy in the current era of less frequent irruptions. ${ }^{24 a} A$ road-killed bird south of Grand Rapids was Joel Kayer's only WIPT observation during the 201920 winter (email, 8 June 2020).

Long-time bird columnist
Alexander G. Lawrence mentioned reports of WIPT between Poplar River and Berens River (about $52.6^{\circ} \mathrm{N}$, 97. $2^{\circ} \mathrm{W}$ ) on 15 November 1926, and earlier at Black Bear Island. ${ }^{25 a}$ He subsequently noted that WIPT "migrates regularly south in winter to Norway House, and very occasionally to more southern points". ${ }^{25 b}$

Further scattered reports in the early 20th century included the first of five definite North Dakota records in 1909 and the first Minnesota record in 1914. ${ }^{26,27}$ The Ward brothers, who Percy A. Taverner described as "unusually well informed sportsmen naturalists", knew of five ptarmigan killed in winter near Shoal Lake[s] (west of the south end of Lake Winnipeg) some time prior to $1917 .{ }^{28}$ Lawrence cited an observation by $\mathrm{N}$. (presumably
Norman) Criddle of several WIPT at Aweme for a few days during the winter of 1917-18.25b Writing in 1964, Harold Mossop mentioned seeing a flock of 18 WIPT in St. Vital (Winnipeg) 40 years previously in January 1924. ${ }^{29}$ Mossop (1908-1973) was just 15 years old at the time of this sighting, but he went on to describe the 1933-34 invasion, so the 1924 date does not seem to be in error. ${ }^{29}$ Bent gave extreme migration dates for Winnipeg of 12 January and 21 March (no source or years given), but this may refer to a larger region than the city alone. ${ }^{30} \mathrm{He}$ also noted tersely that WIPT migration in general "has no regularity". ${ }^{30}$

Saskatchewan - Historical records at Cumberland House and Prince Albert, as compiled in Birds of Saskatchewan, suggest a change

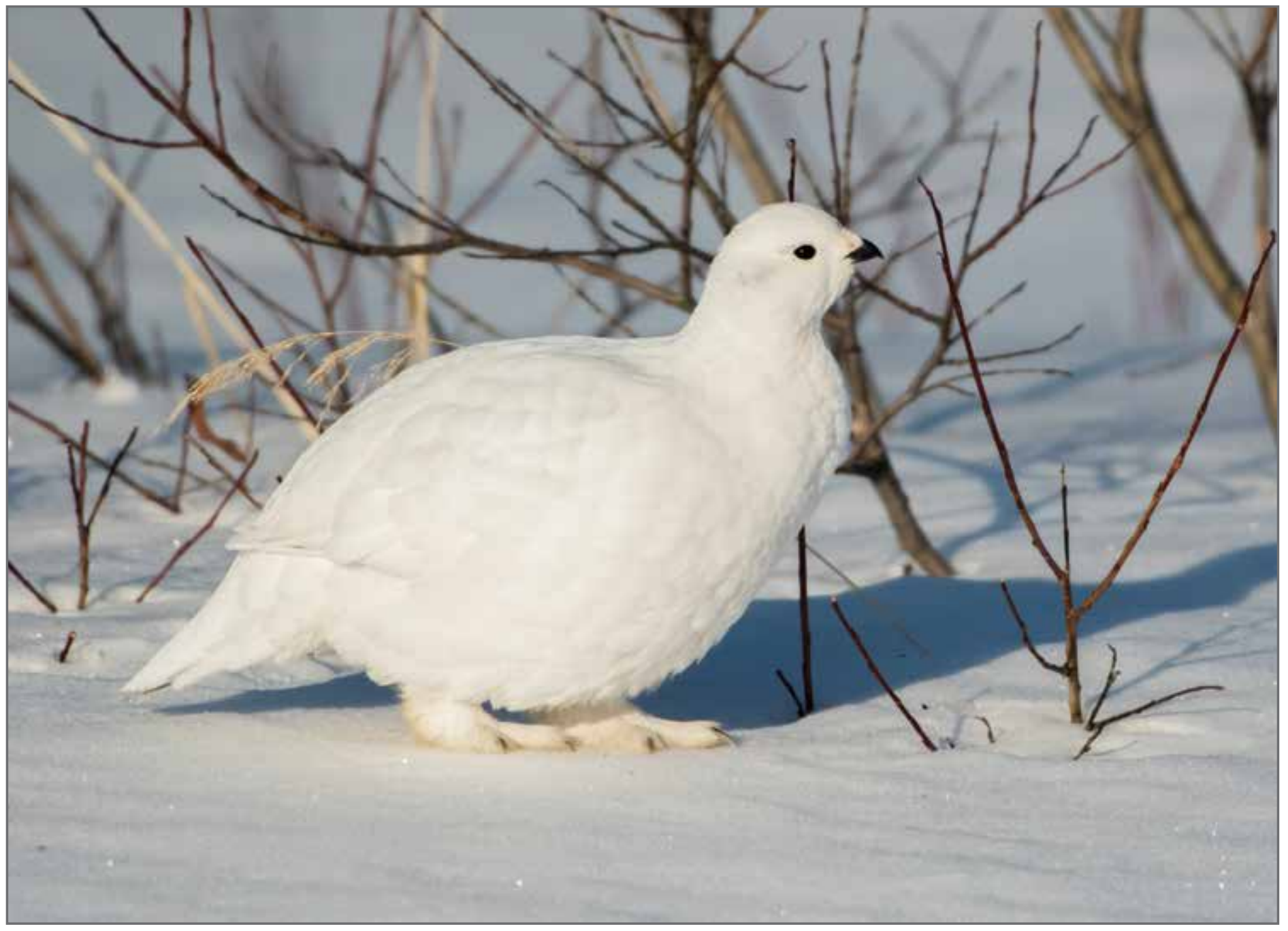

FIGURE 3: This Willow Ptarmigan was one of six seen near Deschambault Lake, Saskatchewan on 7 April 2018. Photo credit: Annie McLeod. 


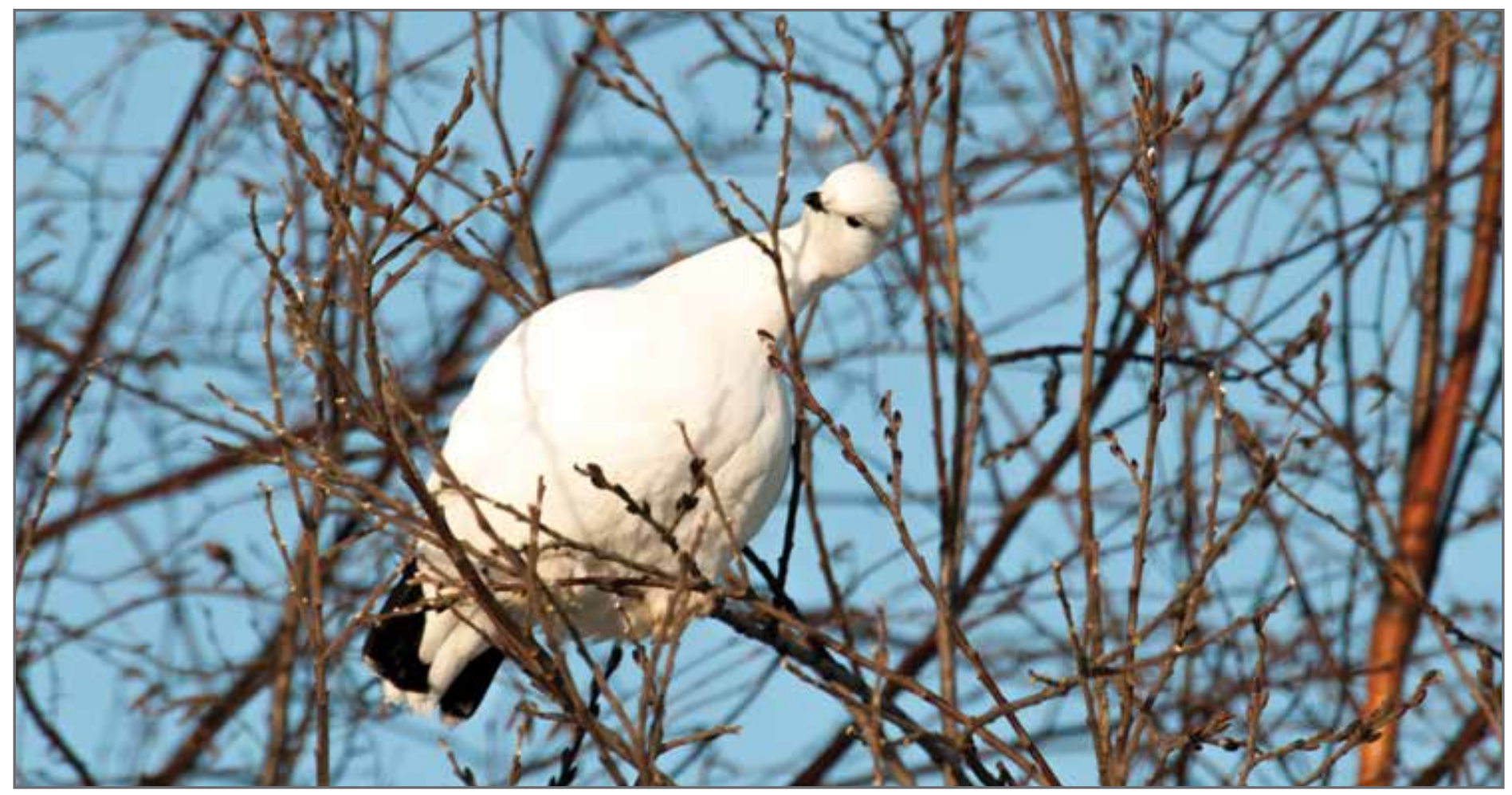

FIGURE 4: A feeding Willow Ptarmigan selects a bud at Creighton, Saskatchewan on 30 December 2008. Photo credit: Harvey Schmidt.

of WIPT status from regular and abundant in winter from around 1820 to the 1880 s (though perhaps not annual by the 1850s), thereafter becoming much scarcer and probably limited to severe winters. ${ }^{3}$ Based on Atlas of Saskatchewan Birds, the southern limit of normal occurrence in Saskatchewan since 1966 is near $54^{\circ} \mathrm{N}$ and $53^{\circ} \mathrm{N}$ at the Alberta and Manitoba boundaries, respectively. ${ }^{13}$ Earlier records extend about 1.5 degrees of latitude $(\sim 170 \mathrm{~km})$ farther south, consistent with a northward range reduction away from the Parklands region. ${ }^{13}$

Alberta - Salt and Salt stated that WIPT normally move south in winter to about $57^{\circ} \mathrm{N}$ in Alberta, but have been recorded as far south as Sullivan Lake as mentioned also by Godfrey. 4,7 Summarizing the species' winter habitat, they wrote that WIPT "...frequent frozen muskegs, the borders of lakes and streams, and similar openings in the woods [but] in some years... they move further south into settled regions... [adding] cultivated grains to their usual diet of berries and buds." They did not mention specific years of southward irruptions. ${ }^{7}$ The reference to cultivated grains recalls the 193132 incursion in Saskatchewan (see p. 19), when ptarmigan frequented farmyards and grain elevators in the Nipawin region. ${ }^{3}$

\section{Southerly incursions in the Prairie Provinces}

It is difficult with 19th and early 20th century records (up to 1930) to distinguish between irruption years and then-regular (annual or near-annual) occurrences, and usually impossible to tell if scattered southern occurrences reflected large movements in more remote regions. There is no doubt, however, that several major southward incursions took place in the early $1930 \mathrm{~s}$.

1930-1931 - A harbinger of a Manitoba irruption was a "beautiful skin" collected by Sam Waller on 13 November 1930 near Gypsumville and sent to Dr. H. M. Speechly (present status of specimen unknown). ${ }^{25 b}$ In correspondence with Lawrence, Waller said the ptarmigan came south "around the time of the great blizzard in October [1930]" and were still present in considerable numbers at Gypsumville when he collected this specimen. He added that many local First Nation residents had never seen a ptarmigan before. $^{25 b}$ This was probably the first of more than 20 WIPT specimens collected by Waller in central Manitoba (mostly at or near Gypsumville and The Pas) and now distributed among several museums in Canada and the U.S., including the Sam Waller Museum in The Pas. ${ }^{23}$

A dozen more observations between 5 November 1930 and 23 April 1931, mentioned by Lawrence (citing numerous observers) were mostly within the ranges of latitude $51-52^{\circ} \mathrm{N}$ and longitude 97-101 ${ }^{\circ} \mathrm{W}^{25 \mathrm{~b}-\mathrm{g}}$ The most southerly report was from Rev. O. Chagnon at Sandy Bay on Lake Manitoba. East of Lake Winnipeg, two specimens were collected at English Brook on 15 January 1931 and are preserved at the Provincial Museum of Alberta. ${ }^{23}$ 
While most reports involved fewer than 10 birds, "large numbers" were present around the southern shore of Lake Winnipegosis, with 1,000 to 2,000 estimated about 15 miles north of the community of Winnipegosis (about $51.8^{\circ} \mathrm{N}$, 99.95W), while "hundreds" were reported farther northwest around Birch River. ${ }^{25 d-f}$ Ptarmigan were also "fairly abundant about the base of the northern escarpment of Riding Mountain, and sparsely scattered throughout the Dauphin district (around $51^{\circ} \mathrm{N}, 101^{\circ} \mathrm{W}$ ). ${ }^{25 i}$

Though writing for a Winnipeg newspaper, Lawrence had correspondents in Alberta, Saskatchewan, and Ontario as well as Manitoba. Concurrent with the 1930-31 WIPT incursion in Manitoba, he mentioned sightings in Saskatchewan at Norquay in mid-December and about 50 miles north of North Battleford ( 53.3N, 108.3 W, "common", undated). ${ }^{25 c, d}$ The Birds of Saskatchewan mentions a southerly record from that winter at Mozart. ${ }^{3}$

Farley collected a male in full summer plumage south of Camrose, $A B$, on 16 May 1931.31 He was aware of only one previous Alberta record south of the North Saskatchewan River, in the South Edmonton area "in winter, some years ago". ${ }^{31}$ The unseasonable date seems to match the pattern of some extreme southerly records in Ontario and the northeastern United States. ${ }^{18,32-35}$ It is possible that at least some such individuals are misoriented spring migrants rather than lingering winter birds.

1931-32 - Though WIPT were noted regularly in winter at Nipawin, Saskatchewan during the 1930s, the greatest influx occurred between 6 November 1931 and 3 April 1932, when ptarmigan frequented farmyards and grain elevators southward to Codette and Pontrilas. ${ }^{3}$
Additional Saskatchewan records in 1931 at Maidstone, Carruthers, and Fort Pitt (all in a band between 52.8 and $53.6^{\circ} \mathrm{N}$ ) likely also refer to this winter. ${ }^{3}$ There is no indication in Lawrence's columns of any comparable movement in Manitoba, but a specimen taken by Waller at Gypsumville is dated 10 March 1932 and preserved at the Royal Ontario Museum (ROM). 23,36

1932-33 - This winter seems to have brought only a modest movement of WIPT to central Manitoba, with Lawrence receiving only two reports from the Dauphin region. ${ }^{25 h, i}$ Three Gypsumville specimens, taken by Waller on 2, 11, and 17 February 1933 are in the ROM collection. This winter does not receive special mention in The Birds of Saskatchewan, nor does it feature in other specimen records for the Prairie Provinces and NW Ontario on GBIF. 3,23 Some mentions of WIPT in central Ontario and parts of Québec around 1932 and 1933 are uncertain or ambiguous about the specific winter(s). 37,38

1933-34 - The winter of 193334 brought noteworthy southward movements by WIPT to southeastern Manitoba and northern Minnesota, as well as parts of Alberta and Ontario, but apparently not Saskatchewan. 2,3,39,40

In Manitoba, many observations were concentrated at the south end of Lake Winnipeg, including five localities within latitude $50.3-50.7^{\circ} \mathrm{N}$ and longitude $96.4-97.0^{\circ} \mathrm{W} .{ }^{25 k-}$ $m, 41 c$ Fred J. Rogers said it was not uncommon to see 20 at a time in the Hillside Beach area, and suggested that the arrival of WIPT was "apparently the result of the extremely cold November weather", a comment echoed 30 years later by Mossop's reference to "a particularly wintry 1933 November". ${ }^{25 k, 29}$ Additional reports extended south to the Whitemouth area and the
Murray Park district of Winnipeg, and west to the East Bay area at Dauphin Lake. ${ }^{25, n-p}$ "Hundreds" were present along the north shore of Lake Manitoba. ${ }^{25 p}$ It was evidently a bumper winter for WIPT within their normal winter range, with "thousands" between Gods Lake and Norway House on 10 December 1933 (A.A. Campbell). ${ }^{25 n}$

In Alberta, Farley reported a major influx "immediately north and east of Edmonton". ${ }^{39}$ He attributed this irruption to deep snows and extremely low temperatures farther north, mentioning temperatures near $-50^{\circ} \mathrm{C}$ in the lower Mackenzie region. Specific communities he mentioned were Ardrossan, Ashmont, Athabasca, and Tawatinaw (all within 53.5-54.8 $\left.\mathrm{N}, 111.5-113.5^{\circ} \mathrm{W}\right)$. From the same region, 10 Donatville specimens and one from Boyle, collected between 6 December 1933 and 5 February 1934, are in the ROM collection (nine birds), the Slater Museum at Puget Sound, and the Peabody Museum at Yale University. ${ }^{23}$ Lawrence received a description of one a little farther west at Barrhead about 18 December 1933. ${ }^{251}$ The ROM collection of WIPT specimens also includes four collected at Red Lake, Ontario on 12 December 1933 and two in the Timiskaming area in January 1934. ${ }^{23}$ Three from Smoky Falls on 3 December 1933 were only about $200 \mathrm{~km}$ from the southern tip of James Bay, and therefore perhaps within the range of normal migration. ${ }^{23}$

The 1933-34 incursion yielded an astonishing 200+ WIPT observations between 7 December 1933 and 25 April 1934 in northernmost Minnesota (Roseau, Lake of the Woods, and northern St. Louis counties), substantiated by three specimens held by the J. F. Bell Museum in Minneapolis. ${ }^{23,40}$ There are only two other confirmed Minnesota records (in 1914 and 
1964) plus some hearsay reports, and no record of comparable invasions in other northern states. ${ }^{26,40}$

1934-35 to present - Contrasting with the great winter movements of 1930-31 and 1933-34, WIPT were scarce in 1934-35 even in their normal winter territory at Island Lake and Gods Lake. ${ }^{25 r}$ The only further reports mentioned by Lawrence came from the Whitemouth area in November 1935 and February 1939, and Dauphin Lake in January 1937 and January 1941. ${ }^{25 s, u, w}$ Near the southern limit of normal movements, however, Waller reported "considerable numbers" in February 1940 near The Pas, where he also collected a specimen on 27 November 1939.25v,41d

Also at The Pas, WIPT were "common everywhere in the district" in February 1950, and they were "more plentiful than usual" in January 1954 farther north at Sherridon, Manitoba. ${ }^{25 x, y}$ As well as the 1939-40 and 1949-50 winters, Waller secured specimens at or near The Pas in December 1950, January 1951 and 1956, and March 1960 and 1962.23,41d,e $A$ series of 23 specimens from Lac la Ronge, Saskatchewan at the University of Michigan Museum of Zoology, obtained in January and February 1949, is apparently linked to an unsuccessful attempt to introduce WIPT in Michigan, and suggests a strong movement in central Saskatchewan that winter. ${ }^{5,23}$ While WIPT migration and wintering in northern Saskatchewan is an annual event, the only hint of southward invasion numbers in Saskatchewan since the 1930s is an often-cited migrating flock of 2,000 WIPT near Creighton in March 1973.3,10

Citing the season's bird summary in Audubon Field Notes, Sadler and Myres noted that WIPT moved farther south in Alberta during winter and spring 1961 than for many years, and were "extremely numerous" at Athabasca. ${ }^{42}$ This is substantiated by five Athabasca specimens, taken in December 1960, at the University of Alberta Museum, Edmonton. Although there seems to be no published account of a ptarmigan invasion in either Saskatchewan or Manitoba that winter, the Manitoba Museum has two southerly specimens taken in January 1961: one from Lake Winnipeg SW of Reindeer Island $\left(\sim 52.3^{\circ} \mathrm{N}, 98.0^{\circ} \mathrm{W}\right)$ on the 6 th, and one from Homebrook, near the north shore of Lake Manitoba on the 11th. ${ }^{41 a, b}$

Records are sparse for WIPT in southern Manitoba from 1962 to 2016. Two in winter plumage were reported at Winnipeg in 1963 on 9 December and an earlier date. ${ }^{29}$ Near the normal winter range limit, large flocks NW of Norway House in February 1964 were reported to Fowke. ${ }^{43}$ Höhn implied, without details, that ptarmigan were present during winter near The Pas and Grand Rapids in the 1970s. ${ }^{10}$ There was a flurry of more southerly reports in December 1986: two surprisingly in summer or transitional plumage at Winnipeg on the 2nd; one in transitional plumage near Marquette early in the month (Perry Hildebrandt); two near Vogar about the 20th and one roadkill east of Lake Manitoba Narrows on the 27th. ${ }^{24 b, c}$ David Raitt recorded two WIPT along Highway 60 near the north shore of Lake Winnipegosis $\left(\sim 52.98^{\circ} \mathrm{N}, 99.94^{\circ} \mathrm{W}\right)$ on 23 December 2013 (eBird).

The southernmost occurrences in Saskatchewan in the last 65 years involved single birds north of Dafoe on 20 February 1964, wintering at Sheho until 21 May 1958, and in the extreme southeast at Carnduff on 6 December 1981. 3,13,44 Höhn implied occurrence near Smeaton in the early 1970s. ${ }^{10}$ The most southerly WIPT record in Saskatchewan on eBird was east of Prince Albert on 15 December 2014.

\section{Note on Rock Ptarmigan}

Other ptarmigan species present an identification challenge, but do not substantially affect the current review because of limited range overlap, though a few individual ptarmigan may have been misidentified. Arctic populations of Willow and Rock Ptarmigan ( $L$. muta, ROPT) overlap, but ROPT has a more northerly range in both summer and winter, and does not normally occur farther south in winter than about Gillam, Manitoba and Uranium City, Saskatchewan. ${ }^{45,46}$ There is one substantiated Alberta record at Garden River (18 December 2011), while Ontario records are mostly along or near the Hudson Bay coast. ${ }^{47,48}$ Exceptional records of individual ROPT in southern Saskatchewan in April and northern Minnesota (and possibly also NW Ontario) in May suggest misoriented spring migration, as with some unseasonal Willow Ptarmigan records discussed on p. 19.46,49,50

In 1931, Lawrence wrote: "a specimen of the Rock Ptarmigan has arrived in Winnipeg, which was found in Saskatchewan, north and west of The Pas in early March [1931]". ${ }^{25 f}$ I am unable to trace this specimen, which pre-dates the seven accepted Saskatchewan records. ${ }^{46}$

Occasionally, leucistic individuals of other grouse species or Gray Partridge (Perdix perdix) have been misidentified as ptarmigan, but this is also not significant to this review. ${ }^{25 j, a}$

\section{Discussion}

Each year, Willow Ptarmigan concentrate in southern parts of their Low Arctic breeding range and move varying distances and in varying (but apparently declining) numbers into the boreal forest. $2,3,8-10$ 
One can imagine a series of zones progressing south across the boreal forest from the southern breeding limit, in which the winter occurrence of WIPT is: (a) "annual" in large numbers; (b) "normal", with large numbers at least once a decade, and possibly cyclic; (c) "limited" to stray individuals or small groups and sporadic irruptions (intervals may be many decades, possibly historic only in some regions); and (d) "vagrant" individuals only. Taking a north-south line near the ManitobaSaskatchewan border as an example, these zones appear to extend south to about (a) Creighton and Flin Flon; (b) The Pas; (c) the "mountains" of the Manitoba Escarpment and adjacent plains; (d) just south of the U.S. border. Data are too sparse to plot the entire winter range in such detail, but Figure 2 includes my estimate of the limit of normal winter occurrence in the Prairie
Provinces, plus the known extent of some major irruptions and some isolated southerly records. The range boundary in Birds of North America is farther south, corresponding roughly to "limited" occurrence as defined above. ${ }^{5}$ The estimated limit of normal occurrence has a slight diagonal trend across Canada, as do the range limits of many birds and other organisms, being farther north $\left(\sim 57^{\circ} \mathrm{N}\right)$ in Alberta and dipping south from $\sim 53^{\circ} \mathrm{N}$ at the Manitoba-Ontario border to $\sim 50^{\circ} \mathrm{N}$ in eastern Ontario and Québec.7,12 This reflects the more southerly latitude of the Taiga Shield and northern Boreal Shield Ecozones in eastern than western Canada. ${ }^{51}$

Irruptive movements well south of the normal winter range appear to be sporadic rather than cyclic, occurring at intervals from one or two years (as in the 1930s) to several decades. In North America, some WIPT populations show peaks at roughly 10-year intervals, though there is evidence of recent breakdown of such cycles, especially the loss of major peaks, perhaps due in part to climate change. . $^{1216}$ Individual irruptions seem to be limited to one or more portions of the continental range, but this may be partly due to limited coverage and reporting in remote regions. Many anecdotal reports associate irruptions with severe weather, i.e., extreme cold or major winter storms, which might result in localized southward displacements. Direct, storm-blown displacement seems unlikely, since ptarmigan migration appears to involve relatively short-range, lowaltitude flight stages, even "walking much of the way" according to Taverner (Figure 5). ${ }^{10,52}$ Writing about WIPT movements in the Labrador Peninsula, Harper noted: "The local bushmen said that when the "White Partridges" come down, it is

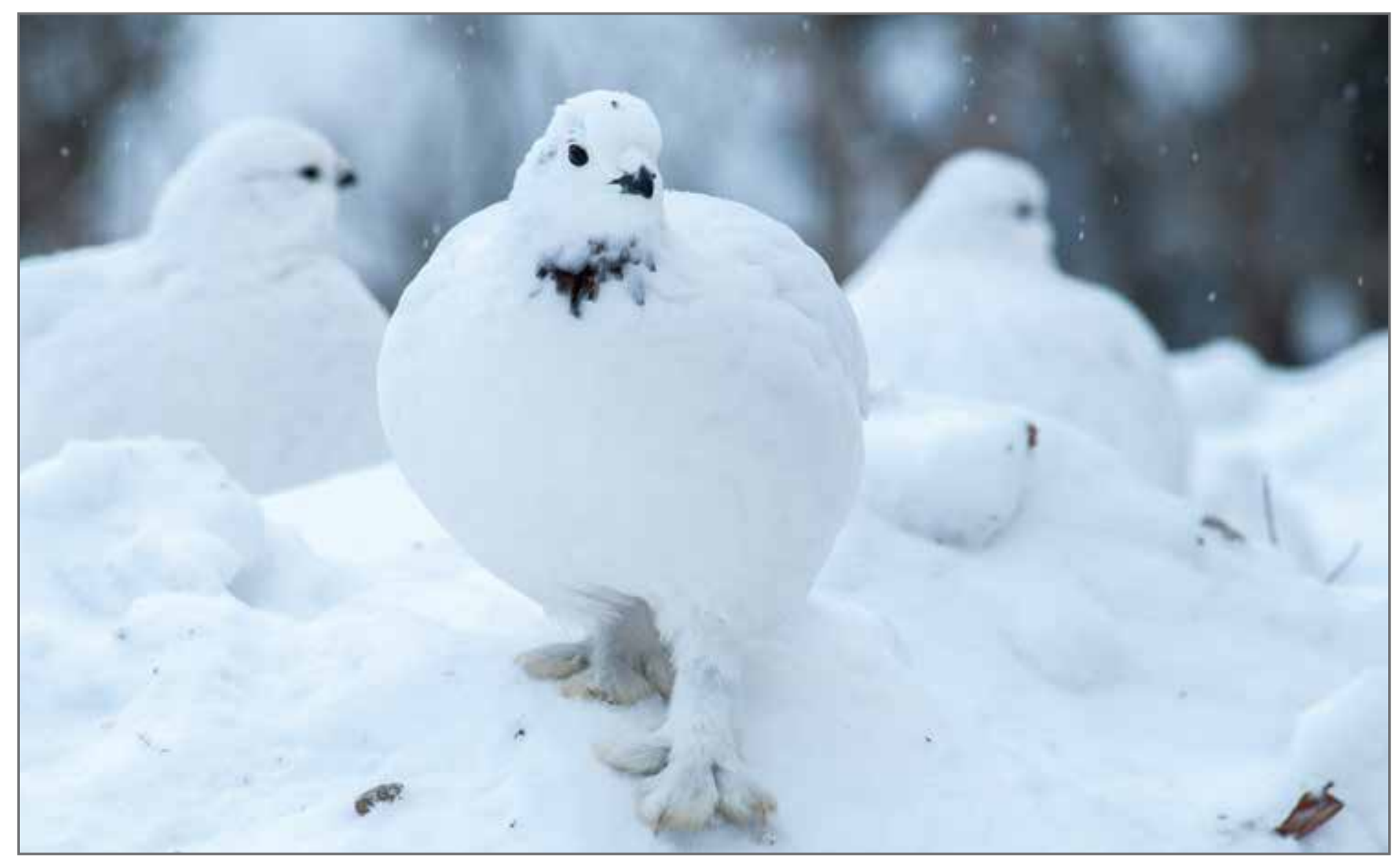

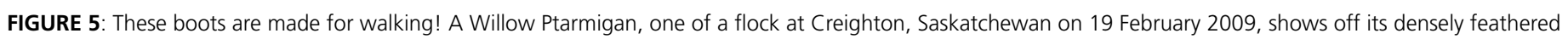
"snowshoes". Note that it has just commenced moulting into breeding plumage. Photo credit: Harvey Schmidt. 
usually because of sleet in the more northerly areas where they usually pass the winter". ${ }^{9}$ This makes sense, because sleet could lead to crusting of the snow, making it difficult for ptarmigan to roost under the snow surface, as well as encapsulating their food supply of twiglets and buds in ice.

Sporadic irruptions by northern Sharp-tailed Grouse (Tympanuchus $p$. phasianellus), e.g., in 1865-66, 189697, 1932-33, 1967-68, and 1968-69 in central Ontario, have been linked to exceptionally high population levels. ${ }^{53-55}$ Unusual southerly records of at least a few WIPT coincided with most if not all of these movements. Summarizing the findings of several researchers around 1990, Hannon et al. described WIPT migration thus: "Movements [are] precipitated by snow cover on breeding sites; birds move to areas with greater vegetative cover, possibly to escape predation, but not because of food shortage". ${ }^{5}$ However, this summary seems to refer to normal migration rather than sporadic irruption. Donald Hooper attributed the gradual diminution of ptarmigan migration in Saskatchewan to the gradual advance of settlement and farming. ${ }^{56}$

The population dynamics of WIPT is a complex subject of extensive research throughout its circumpolar range, as summarized in a recent, multi-author review. ${ }^{57}$ While Yukon populations have been monitored closely for several decades, data are apparently sparse for the central Canadian Arctic, whence many of the migrants that reach the southern Prairie Provinces likely originate. ${ }^{16,57}$ Whatever drives and limits the most southerly winter movements, I feel privileged to have witnessed one of the extreme occurrences in southeastern Manitoba in December 2017. These were apparently the first records so far south in Manitoba since 1986, and the first southeast of Lake Winnipeg since the 1930s.

\section{Acknowledgements}

The following correspondents provided valuable information: Garry Budyk, Dennis Fast, Charissa Godfrey, Richard Farquhar, Gordon Grieef, Joel Kayer, Rudolf Koes, Katherine Patterson, David Raitt, Daniel Seales (Manitoba); Stuart Houston, Harvey Schmidt (Saskatchewan); James Fox (Alberta); David Elder, Brian Ratcliff, Devin Turner, Josh Vandermeulen (Ontario); Pierre Bannon, Normand David (Québec); Adam Byrne (Michigan); Peder Svingen (Minnesota); Ron Martin (North Dakota); Andrew Rapp (Virginia). Special thanks are due to Randall Mooi, Curator of Zoology at The Manitoba Museum, for access to specimen information, copies of Chickadee Notes columns, and many other resources. I also thank Anita Drabyk, Randall Mooi, Brian Ratcliff, and Spencer Sealy for helpful comments on a draft manuscript.

All websites cited below were verified on 12 August 2020.

\section{Audubon Christmas Bird Count. http:// www.audubon.org/conservation/science/ christmas-bird-count.}

2. Holland GE, Taylor P (2003) Willow Ptarmigan. In: Manitoba Avian Records Committee, The Birds of Manitoba, Manitoba Naturalists Society, Winnipeg, Manitoba, p. 151.

3. Schmidt B (2019) Willow Ptarmigan. In: Birds of Saskatchewan (A. R. Smith, C. S. Houston, J. F. Roy, editors), Nature Saskatchewan, Regina, p. 131.

4. Godfrey WE (1986) The birds of Canada. Revised edition. National Museum of Natural Sciences, Ottawa, Ontario.

5. Hannon SJ, Eason PK, Martin K (1998) Willow Ptarmigan (Lagopus lagopus), version 2.0. In: The Birds of North America (A. F. Poole and F. B. Gill, Editors). Cornell Lab of Ornithology, Ithaca, New York. https://doi. org/10.2173/bna.369 .
6. Artuso C (2018) Willow Ptarmigan. In: Artuso C, Couturier AR, De Smet KD, Koes RF, Lepage D, McCracken J, Mooi R, Taylor $P$ (Eds.) (2018). The Atlas of the Breeding Birds of Manitoba, 2010-2014. Bird Studies Canada. Winnipeg, Manitoba. http://www. birdatlas.mb.ca/accounts/speciesaccount. jsp?sp=WIPT\&lang=en .

7. Salt WR, Salt JR (1976) The birds of Alberta with their ranges in Saskatchewan and Manitoba. Hurtig, Edmonton, Alberta.

8. Jehl JR Jr (2004) Birdlife of the Churchill region: status, history and biology. Trafford Publishing, Victoria.

9. Harper F (1958) Birds of the Ungava Peninsula. University of Kansas, Lawrence.

10. Höhn EO (1984) Willow Ptarmigan in the boreal forest of the Prairie Provinces. Blue Jay 42:8388.

11. Weeden RB (1964) Spatial separation of sexes in Rock and Willow Ptarmigan in winter. The Auk 81:534-541.

12. Lamothe P, Doyon M-R (1996) Willow Ptarmigan. In: The breeding birds of Québec: Atlas of the breeding birds of southern Québec (J. Gauthier and Y. Aubry, eds.). Province of Québec Society for the Protection of Birds and Canadian Wildlife Service, Montréal, Québec, pp. 422-425.

13. Smith AR (1996) Atlas of Saskatchewan birds. Special Publication No. 22, Saskatchewan Natural History Society, Regina.

14. Peterson RT, Peterson VE (1980) A field guide to the birds [east of the Rockies]. Fourth Edition, Houghton Mifflin, Boston.

15. Skok A (2017) Hunting ptarmigan in winter: the 5 things you need to know. https://www.outdoorcanada.ca/huntingptarmigan-in-winter-the-5-things-you-needto-know/

16. Mossop DH (2011) Long-term studies of Willow Ptarmigan and Gyrfalcon in the Yukon Territory: A collapsing 10-year cycle and its apparent effect on the top predator. In: Gyrfalcons and ptarmigan in a changing world (conference proceedings), The Peregrine Fund, Boise, Idaho. Vol. 1, pp. 323-336.

17. Fleming JH (1907) Birds of Toronto, Canada. Part II, Land birds. The Auk 24:7189.

18. Burrell MVA, Charlton BN, Burrell KGD Vandermeulen JD, Lamond WG, Lucas TB, Mann BA, Pratt PD, Sutherland DA (2018) 
Ontario Bird Records Committee Report for 2017. Ontario Birds 36:58-88.

19. Fleming JH (1901) A list of the birds of the districts of Parry Sound and Muskoka, Ontario. The Auk 18:33-45.

20. Speirs JM (1985) Birds of Ontario. Natural Heritage / Natural History Inc., Toronto, Ontario. Volume II, p. 207.

21. Thompson [Seton] EE (1890) The birds of Manitoba. Proceedings of the U.S. National Museum 13:457-643 [No. 841]. As reprinted in "Ernest Thompson Seton in Manitoba 1882-1892" (with introduction by C.S. Houston), Premium Ventures Ltd. and Manitoba Naturalists Society, Winnipeg, Manitoba, 1980.

22. Russell $F$ (1898) Explorations in the Far North. University of lowa, pp. 260-261.

23. Global Biodiversity Information Facility, https://www.gbif.org/ and VertNet, https:// www.vertnet.org/. There is substantial overlap between these two database portals.

24. Hatch DRM (various years) Chickadee Notes, Winnipeg Free Press. (a) 16 Feb 1979, (b) 17 Jan 1987, (c) 14 Feb 1987.

25. Lawrence AG (various years) Chickadee Notes, Winnipeg Free Press. (a) No. 306, 3 Feb 1927, (b) No. 504, 21 Nov 1930, (c) No. 512, 16 Jan 1931, (d) No. 517, 20 Feb 1931, (e) No. 520, 13 Mar 1931, (f) No. 523, 3 Apr 1931, (g) No. 529, 15 May 1931, (h) No. 615, 6 Jan 1933, (i) No. 620, 10 Feb 1933, (j) No. 628, 7 Apr 1933, (k) No. 664, 15 Dec 1933, (l) No. 666, 29 Dec 1933, (m) No. 668, 12 Jan 1934, (n) No. 673, 16 Feb 1934, (o) No. 674, 23 Feb 1934, (p) No. 679, 30 Mar 1934, (q) No. 707, 12 Oct 1934, (r) No. 729, 15 Mar 1935, (s) No. 776, 7 Feb 1936, (t) No. 824, 8 Jan 1937, (u) No. 935, 24 Feb 1939, (v) No. 987, 23 Feb 1940, (w) No. 1039, 21 Feb 1941, (x) No. 1501, 24 Feb 1950, (y) No. 1707, 5 Feb 1954.

26. Roberts TS (1932) The birds of Minnesota. University of Minnesota Press, Minneapolis (two volumes).

27. Martin R (North Dakota Bird Records Committee). Personal communication, email, 5 March 2018.

28. Taverner PA (1918 and 1919) The birds of Shoal Lake, Manitoba [published in three parts], Ottawa Naturalist 32:137-144 and 157-164; Canadian Field-Naturalist 33:12-20.

29. Mossop H (1964) Chickadee Notes, Winnipeg Free Press. No. 468 (second series), 4 Jan 1964.
30. Bent AC (1932) Life histories of North American gallinaceous birds. U.S. National Museum Bulletin No. 162, Smithsonian Institution, Washington, DC.

31. Farley FL (1932) Willow Ptarmigan, Lagopus lagopus, in central Alberta in May. Canadian Field-Naturalist 46:208-209.

32. Applegate RD (1996) Extralimital occurrences of Willow Ptarmigan, Lagopus lagopus, in Maine. Canadian Field-Naturalist 110:715.

33. Massachusetts Avian Records Committee (2009) Thirteenth Annual Report of the Massachusetts Avian Records Committee (MARC), http://maavianrecords.com/annualreports/13th/.

34. Vermont Bird Records Committee (2019) An annotated list of vagrant, out-of-season and rare nesting birds of Vermont. https:// vtecostudies.org/wildlife/wildlife-watching/ vbrc/annotated-bird-list/.

35. New York State Avian Records Committee (2016) Special report of the New York State Avian Records Committee: Addition of six new species to the New York checklist. The Kingbird 66: 264-274.

36. Shortt TM, Waller S (1937) The birds of the Lake St. Martin region, Manitoba. Contributions, Royal Ontario Museum, Zoology 10:1-51.

37. Smith WJ (1957) Birds of the Clay Belt of Northern Ontario and Quebec. Canadian Field-Naturalist 71:163-181.

38. Brassard JA, Bernard R (1937) Willow Ptarmigan at the Quebec Zoological Gardens. The Auk 54:514-515.

39. Farley FL (1934) Unusual migration of Willow Ptarmigan into central Alberta during the winter of 1933-34. Canadian FieldNaturalist 48:120.

40. Janssen RB (1987) Birds in Minnesota: a field guide to the distribution of 400 species of birds in Minnesota. University of Minnesota Press, Minneapolis.

41. The Manitoba Museum, Winnipeg, Willow Ptarmigan specimens, (a) 1-2-2203, (b) 1-2-2384, (c) 1-2-2425, (d) 1-2-2552, (e) 1-2-2553.

42. Sadler TS, Myers MT (1976) Alberta Birds 1961-1970. Occasional Paper \#1, Provincial Museum of Alberta, Edmonton, Alberta.

43. Fowke SC (1964) Winter birds of Norway House. Blue Jay 22:56-57.
44. Taylor RR (1964) A southerly record of the Willow Ptarmigan. Blue Jay 22:57.

45. Larche RA, Sealy SG (1977) Inland records of the Rock Ptarmigan in Manitoba. Blue Jay 35:99-100.

46. Dickson RD (2019) Rock Ptarmigan. In: Birds of Saskatchewan (A. R. Smith, C. S. Houston, J. F. Roy, editors), Nature Saskatchewan, Regina, p. 132.

47. Kuipers K, Kuipers N, Storer P (2012) Rock Ptarmigan - a new bird for Alberta. Blue Jay 70:56-57.

48. Lumsden HG (1964) The Rock Ptarmigan, Lagopus mutus rupestris, in Ontario and Manitoba. Canadian Field-Naturalist 78:161167.

49. Hoffman K (1996) A Rock Ptarmigan at Grand Marais [Minnesota]. The Loon 68:79.

50. Eckert KR (1996) Some additional comments on the Rock Ptarmigan in Grand Marais [Minnesota]. The Loon 68:80-81.

51. Canadian Council on Ecological Areas (2014) Ecozones of Canada Version 2014.02. https://www.ccea.org/Downloads/shapefiles/ CA_ecozones_1M_v5_final_map \%20 v20140213.pdf.

52. Taverner PA (1926) Birds of Western Canada. Department of Mines, Ottawa (reprinted, 1974, Coles, Toronto).

53. Lumsden HG (2005) "Prairie Grouse", Tympanuchus cupido X phasianellus, hybridization on Manitoulin Island, Ontario. Canadian Field-Naturalist 119:507-514.

54. Elder DH (1979) Birds of the Geraldton district. Ontario Field-Biologist 33:26-41.

55. Escott NG (2003) The Sharp-tailed Grouse in Thunder Bay District. Ontario Birds 21:214.

56. Hooper DF (1992) Birds of east-central Saskatchewan. Special Publication No. 18, Saskatchewan Natural History Society, Regina.

57. Fuglei E, Henden J-A, Callahan CT, Gilg O, Hansen J, Ims RA, Isaev AP, Lang J, Mclntyre CL, Merizon RA, Mineev OY, Mineev YN, Mossop D, Nielsen OK, Nilsen EB, Pedersen $\varnothing$, Schmidt NM, Sittler B, Willebrand MH, Martin K (2020) Circumpolar status of Arctic ptarmigan: population dynamics and trends. Ambio 49(3):749-761.

58. Stanford HP (1914) Willow Ptarmigan in Montana. The Auk 31:399. 